
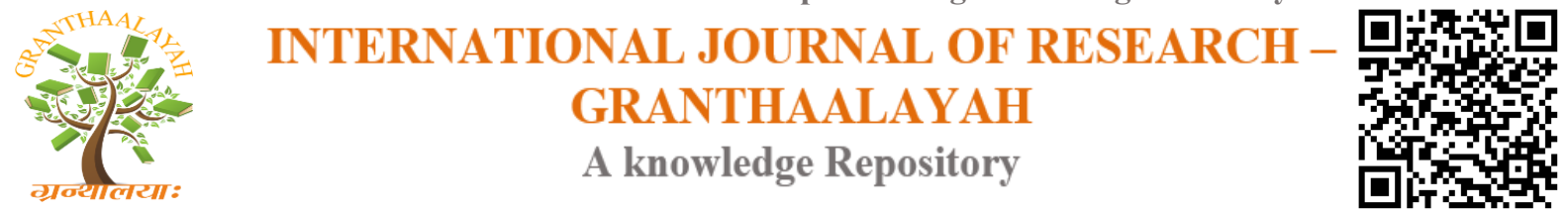

Social

\title{
THE INFLUENCES OF SOME VARIABLES ON ATTITUDES OF SPECIAL EDUCATION TEACHERS TOWARDS EDUCATING PUPILS WITH AUTISM IN REGULAR SETTINGS
}

\author{
Ahmed Elhassan Hamid Hassan*1, Eldood Yousif Eldood Ahmed ${ }^{2}$, Abdul-alaziz Alasmari ${ }^{3}$ \\ ${ }^{*}$ Special Education Department, Collage of Education, Jazan University. K.S.A \\ ${ }^{2}$ Special Education Department, Collage of Education, Jazan University. K.S.A \\ ${ }^{3}$ Special Education Department, Collage of Education, Jazan University. K.S.A
}

\begin{abstract}
All special needs teachers want their children to be accepted by their peers have friends and lead "regular" lives. Inclusive settings can make this vision a reality for many children with disabilities. So that we conducted this study to know the influences of some variables on attitudes of special education teachers towards educating students with autism in regular settings. The researchers used descriptive statistic methods. Questioner technique is used as method of data collection. Study group included 150 special education teachers from Abu Areech Learning administration, 70 teachers were selected randomly as sample. The data was analyzed by using SPSS program. The results are as following: There are no significant differences in attitudes of special education teachers towards inclusive settings according to interaction with disabled, there are no significant differences in attitudes of special education teachers towards inclusive settings according to the class size. There are significant differences in attitudes of special education teachers towards inclusive settings according to the training courses and there are significant in attitudes of special education teachers towards inclusive settings according to the qualification.
\end{abstract}

Keywords:

Autism, Inclusive, Special Education, Teacher, Attitude.

Cite This Article: Ahmed Elhassan Hamid Hassan, Eldood Yousif Eldood Ahmed, and Abdulalaziz Alasmari, "THE INFLUENCES OF SOME VARIABLES ON ATTITUDES OF SPECIAL EDUCATION TEACHERS TOWARDS EDUCATING PUPILS WITH AUTISM IN REGULAR SETTINGS" International Journal of Research - Granthaalayah, Vol. 3, No. 10(2015): 30-37.

\section{INTRODUCTION}

Special education teachers' attitudes influenced by some variable like interaction with disabled children, training courses, qualifications, a study conducted by Ali \& et al (2006) pointed that participants altogether decided that inclusion could raise the level of social interactions and integrations among the students. Bhatnagar \& Das (2014) indicated that educators had more 
interactions with people with disabilities and received more training courses showed more positive attitudes to educate children with special needs in inclusive settings than those who did not. Kiriungi \& et al (2014) indicate that social acceptance influenced educator's attitudes towards inclusive education. Leatherman \& Niemeyer (2005) indicated that, training positively influenced educators' attitudes towards inclusion and imparted them with useful methods to educate all typical and disabled students. Johnson \& et al (2014) indicated that all of the participants had training courses negatively affected educators' attitudes to include children with disabilities in general classes. Hwang \& Evans (2011) indicated that social interactions was one of the benefits that general educators revealed to be demonstrated by all children including with special needs. Parhoon, \& et al (2014) found that educators had lower educational levels revealed higher positive attitudes to include children with disabilities than educators held higher levels of education did. Hsieh \& Hsieh (2012) told that educational level did not influenced educators attitudes to include children with special need. Bhatnagar \& Das (2014) told that the educators held higher degrees whether they were graduate or postgraduate degrees positively showed their attitudes to include children with special needs. Ahmed \& et al (2012) indicated that recent academic qualifications, influenced educators attitudes toward inclusive education. Researchers found that there were a considerable correlation between educators' academic qualifications and attitudes to teach children with disabilities in general classes. Educators held Bachelor's degrees revealed higher attitudes toward inclusive education while educators held Master's degree revealed less attitudes toward inclusive education. Johnson \& et al (2014) indicated that class size negatively affected educators' attitudes to include children with disabilities in general classes. Gal \& et al (2010) found that educators had longer experiences show their concerns about inclusion such as class size. There is a study conducted by Dupoux, \& et al (2006) Researchers found that educators held higher educational degrees revealed more positive attitudes to educate all children in inclusive settings. Galović, \& et al (2014) indicated that educators' attitudes to include children with disabilities were neutrally presented. Educators' attitudes towards inclusive education were not statistically different with respect to their qualification and training courses. Fayed (2011) indicated that there were no significant variances in educators' attitudes to include children with disabilities in general classes with regard to training. There is a study implemented by Buford \& Casey (2012) indicated that there were no significant variances in educators' attitudes to include children with disabilities in general classes with regard to educational level. Astha, \&et al (2011) indicated that educators held higher educational levels held less positive attitudes towards inclusion. Todorovic \& et al (2011) indicated that educators' attitudes to include children with special needs in general classes were not influenced by education level. Boyle \& et al (2013) told that qualified staff did not significantly influenced educators attitudes toward inclusive. Monsen \& et al (2014) told that participants' attitudes to include children with disabilities in general classes were not influences by length of class size.

\section{AIMS OF STUDY}

This conducted to verify:

- Influences of interaction with disabled on Attitudes of special education teachers towards educating students with autism in regular settings.

- Influences of training courses on Attitudes of special education teachers towards educating students with autism in regular settings. 
- Influences of qualification on Attitudes of special education teachers towards educating students with autism in regular settings.

- Influences of the class size on Attitudes of special education teachers towards educating students with autism in regular setting.

\section{HYPOTHESIS}

To achieve the aims of study the researchers the following hypothesis should be verify:

1. There are significant differences in attitudes of special education teachers towards educating students with autism in regular settings according to interaction with disabled.

2. There are significant differences in attitudes of special education teachers towards educating students with autism in regular settings according to the training courses.

3. There are significant in attitudes of special education teachers towards educating students with autism in regular settings according to the qualification.

There are significant differences in attitudes of special education teachers towards educating students with autism in regular settings according to the class size.

\section{MATERIALS AND METHODS}

4.1. Research Method: In this study, the descriptive analytic research technique was used.

4.2. Sample technique: We used the random sample method, the questionnaire was answered by 70 special educational teachers from Abu Areech Learning Administration- Jazan aria - K.S.A during fall 2014-2015 (academic period).

4.3. Tools Technique: We used Teachers Attitude toward Inclusive Education Scale designed by the researchers. It is formed 43 items these items were distributed in two different constructs that are positive attitude and negative attitude. The pilot tests in a random subsample of the educator's community were made, the value of stability counted by Cronbach's alpha coefficient it was 0.85 .

4.4. Practical Procedures: The principle of voluntarism was the precondition of participating in questionnaire. For the questionnaire, an explanation was prepared. The aims of the study and how the study would be carried out were clearly stated in it. In addition, it was emphasized that the identities of the participants would remain confidential during written questionnaire. Study took place about one month from 1/6/2015 to 30/6/2015.

\section{RESULTS AND DISCUSSIONS}

\section{RESULTS}

1. There are significant differences in attitudes of special education teachers towards educating students with autism in regular settings according to interaction with disabled. 
To verify this hypothesis the researchers used independent sample $T$ test as in table (1). When we compare the means, we found that the mean of special education teachers whom interaction with disabled children (106.6) greater than whom have not interaction with disabled children (100.5). These differences are significant at level (0.05). So that there are differences in attitudes of special education, teachers towards educating students with autism in regular settings according to the interaction with disabled children. That means the educator interaction with disabled children have positive attitude.

Table 1: shows differences in attitudes of special education teachers towards educating students with autism in regular settings according interaction with disabled.

\begin{tabular}{|l||l||l||l|l||l||l|l||}
\hline Responses & N & Mean & Std. & T value & df & sig & Result \\
\hline \hline Yes & 58 & 106.6 & 11.762 & 2.254 & 69 & 0.008 & significant \\
\hline \hline No & 13 & 100.5 & 13.087 & & & & \\
\hline
\end{tabular}

2. There are significant differences in attitudes of special education teachers towards educating students with autism in regular settings according to the training courses.

To verify this hypothesis the researchers used independent sample $\mathrm{T}$ test as in table (2). When we compare the means, we found that the mean of special education teachers whom attendance to training courses about inclusive (101.40) is greater than whom have not attendance to training courses about inclusive (97.68). These differences are significant at level (0.05). So that there are, differences in attitudes of special education teachers towards educating students with autism in regular settings according to training courses. That means the educators have attending to course about inclusive have positive attitude.

Table 2: shows differences in attitudes of special education teachers towards educating students with autism in regular settings according to training courses.

\begin{tabular}{|l||c||l|l|l|l||l|l||}
\hline Responses & N & Mean & Std. & T value & df & sig & Result \\
\hline \hline Yes & 40 & 101.40 & 11.593 & \multirow{2}{*}{1.312} & 69 & 0.04 & significant \\
\hline \hline No & 31 & 97.68 & 12.202 & & & \\
\hline
\end{tabular}

\section{There are significant in attitudes of special education teachers towards educating students with autism in regular settings according to the qualification.}

To verify this hypothesis the researchers used independent sample $\mathrm{T}$ test as in table (2). When we compare the means, we found that the mean of special education teachers whom have bachelor degree (101) is greater than whom have diploma (88). These differences are significant at level (0.05). So that there are, differences in attitudes of general and special education teachers towards educating students with autism in regular settings according to qualification. That means the educators have bachelor degree have positive attitude. 
Table 3: shows in attitudes of special education teachers towards educating students with autism in regular settings according to the qualification.

\begin{tabular}{|l|r|r||l|l|l|l|l|}
\hline Responses & N & Mean & Std. & T value & df & sig & Result \\
\hline \hline Bachelor & 44 & 101 & 11.457 & \multirow{2}{*}{2.203} & 6 & .031 & significant \\
\hline Diploma & 23 & 88 & 11.284 & & & & \\
\hline
\end{tabular}

\section{There are significant differences in attitudes of special education teachers towards educating students with autism in regular settings according to the class size.}

To verify this hypothesis the researchers used ANOVA analysis of variance. Table (4) shows the result. As in table (4) the sig value (0.93) is greater than significant level (0.05), this means that there is no significant differences in attitudes of special education teachers towards educating students with autism in regular settings according to the class size.

Table 4: shows the differences in attitudes of special education teachers towards educating students with autism in regular settings according to the class size

\begin{tabular}{|c||c|c|c|c|c|c|}
\hline & Sum of Squares & df & Mean Square & F & Sig. & Result \\
\hline \hline Between Groups & 375.277 & 7 & 53.611 & & & Not significant \\
\hline Within Groups & 9575.118 & 63 & 151.986 & \multirow{2}{*}{.353} & \multirow{2}{*}{0.93} & \\
\hline Total & 9950.394 & 70 & & & & \\
\hline
\end{tabular}

\section{DISCUSSION}

When we analyses the data the study revealed that there are differences in attitudes of special education teachers towards educating students with autism in regular settings according to the interaction with disabled children. Teachers whom interaction with disabled children have positive attitude toward inclusive. This result is in line with study of Bhatnagar \& Das (2014) they found that teachers had more interactions with people with disabilities showed more positive attitudes to educate children with special needs in inclusive settings than those who did not. Ahmed \& et al (2012) indicated that interactions with a pupils with special needs, influenced educators attitudes toward inclusive education. Kiriungi $\mid \&$ et al (2014) indicate that social acceptance influenced educator's attitudes towards inclusive education. In addition, the study indicated that there are significant differences in attitudes of special education teachers towards educating students with autism in regular settings according to the training courses. Teachers have attending to course about inclusive have positive attitude. This result is in line with study of Bhatnagar \& Das (2014) indicated that educators had more training courses showed more positive attitudes to educate children with special needs in inclusive settings than those who did not. Leatherman \& Niemeyer (2005) indicated that training positively influenced educators' attitudes towards inclusion. Hwang \& Evans (2011) indicated that social interactions was influenced on educator's attitude. In addition this result is disagree with study of Johnson \& et al (2014) which indicated that all of the participants had training courses negatively affected educators' attitudes toward inclusive. Ahmed \& et al (2012) indicated that recent academic qualifications, influenced educators attitudes toward 
inclusive education. Galović, \& et al (2014) indicated that educators' attitudes towards inclusive education were not statistically different with respect to their training courses. Fayed (2011) indicated that there were no significant variances in educators' attitudes toward inclusive regard to training. In addition, the study found that there are significant differences in attitudes of special education teachers towards educating students with autism in regular settings according to the qualification. The teachers have bachelor degree have positive attitude. This result is in line with study of Parhoon, \& et al (2014) they found that teachers had lower educational levels revealed higher positive attitudes to include children with disabilities than teachers held higher levels of education did. Bhatnagar \& Das (2014) told that the educators held higher degrees whether they were graduate or postgraduate degrees positively showed their attitudes toward inclusive. In addition this result is not agree with study of Hsieh \& Hsieh (2012) which indicate that educational level did not influenced educators attitudes toward inclusive education. Dupoux, \& et al (2006) found that educators held higher educational degrees revealed more positive attitudes to educate all children in inclusive settings. Ahmed \& et al (2012) indicated that there were a considerable correlation between educators' academic qualifications and attitudes to teach children with disabilities in general classes. Educators held Bachelor's degrees revealed higher attitudes toward inclusive education while educators held Master's degree revealed less attitudes toward inclusive education. Astha, \&et al (2011) indicated that educators held higher educational levels held less positive attitudes towards inclusion. In addition this result is disagree with some study, study conducted by Galović, \& et al (2014) indicated that educators' attitudes towards inclusive education were not statistically different with respect to their qualification. Buford \& Casey (2012) indicated that there were no significant variances in educators' attitudes toward inclusive regard to educational level. Todorovic \& et al (2011) indicated that educators' attitudes toward inclusive were not influenced by education level. Boyle \& et al (2013) told that qualified staff did not significantly influenced educators attitudes toward inclusive. Finally they study revealed that there are no significant differences in attitude of teach children with intellectual disabilities according to the class size. This result is agreed with study of Johnson \& et al (2014) which indicated that class size negatively affected educators' attitudes to include children with disabilities in general classes. Gal \& et al (2010) found that educators had longer experiences show their concerns about inclusion such as class size. Monsen \& et al (2014) told that participants' attitudes toward inclusive education were not influences by length of class size.

In general, the researchers pointed that important implication to the school administrators, teachers and parents who essentially were important parts for the inclusive system process. Indeed, the attitudes of educators can be affected toward including students with disabilities in classrooms when there is certain level of awareness among those general educators. In addition, Researchers indicated that educators believed including students with disabilities in a general settings improved their friendships and relationships with other. So that we believe that children with disabilities were socially accepted in inclusive settings. In addition, we showed that the teachers needed to have training courses and professional developments to include children with disabilities in inclusive settings.

\section{CONCLUSIONS \& RECOMMENDATIONS}

We conducted this study in Jazan university- faculty of education during academic year fall 20142015. The aim of study was to examine the influences of some variables on attitudes of general 
and special education teachers towards educating students with autism in regular settings, we revealed that: There are no significant differences in attitudes of special education teachers towards inclusive settings according to interaction with disabled, there are no significant differences in attitudes of special education teachers towards inclusive settings according to the class size. There are significant differences in attitudes of special education teachers towards inclusive settings according to the training courses and there are significant in attitudes of special education teachers towards inclusive settings according to the qualification.

The researchers recommended that when children attend classes that reflect the similarities and differences of people in the real world, they learn to appreciate diversity. Respect and understanding grow when children of differing abilities and cultures play and learn together. Schools are important places for children to develop friendships and learn social skills. Children with and without disabilities learn with and from each other in inclusive classes.

\section{REFERENCES}

[1] Ahmed, M., Sharma, U., \& Deppeler, J. Variables affecting teachers' attitudes towards inclusive education in Bangladesh. Journal of Research in Special Educational Needs, Vol. 12, No. (3), 2012: 132-140.

[2] Ali, M., Mustapha, R., \& Jelas, Z. An empirical study on teachers' perceptions towards Inclusive education in Malaysia. International journal of special education, Vol. 21, No (3), 2006: 36-44.

[3] Astha, Sushma, S., \& Smriti, B. In-Service Primary Teachers' Attitude towards Inclusion: Survey Results from District Kurukshetra (Haryana). International Journal of Multidisciplinary Research, Vol 1, No (8), 2011:192- 197.

[4] Bhatnagar, N., \& Das, A. K. Attitudes of secondary school teachers towards inclusive education in New Delhi, India. Journal of Research in Special Educational Needs, Vol .14, No (4), 2014: 255-263.

[5] Boyle, C., Topping, K., \& Snape, D. Teachers' attitudes towards inclusion in high schools, Teachers and Teaching: theory and practice, Vol.19, No (5), 2013: 527-542, Buford, S., \& Casey, L. Attitudes of Teachers Regarding Their Preparedness to Teach Students with Special Needs. Delta Journal of Education, Vol. 2, No. (2) 2012:16- 30.

[6] Dupoux, E., Hammond, H., Ingalls. \& Wolman, C. Teachers' Attitudes towards Students with Disabilities in Haiti. International Journal of Special Education, Vol. 21, No (3), 2006: 1 - 14.

[7] Fayed, G (2011). Factors influencing Classroom Practice on Egyptian Teachers Attitudes toward Inclusion. E-Journal of Organizational Learning and Leadership, Vol.9, No. (1).2011: 80- 96.

[8] Gal, E., Schreur, N., \& Yeger, B (2010). Inclusion of Children with Disabilities: Teachers' Attitudes and Requirements for Environmental Accommodations. International Journal of Special Education, Vol. 25, No (2) 2010: 89- 99.

[9] Galović, D., Brojčin, B., \& Glumbić, N. The Attitudes of Teachers towards Inclusive Education in Vojvodina. International Journal of Inclusive Education, Vol 10.2014: 307315.

[10] Hsieh, W., \& Hsieh, C. Urban Early Childhood Teachers' Attitudes towards Inclusive Education. Early Child Development and Care, Vol.182, No (9), 2012: 1167-1184. 
[11] Hwang, Y., \& Evans, D. Attitudes towards Inclusion: Gaps between Belief and Practice. International Journal of Special Education, Vol. 26, No (1) 2011:136- 146.

[12] Johnson, D., Newton, N., \& Johnson, N. What Does Teachers' Perception have to do with Inclusive Education: A Bahamian Context? International journal of special education, Vol. 29, No, (1) 2014:143- 157.

[13] Johnson, J., Johnson, Y., \& Newton, N. Breaking the silence of mainstream teachers' attitude towards inclusive education in the Bahamas: High school teachers' perceptions. The Qualitative Report, Vol. 19, No. (84), 2014: 1-19.

[14] Kiriungi, L., Mwiti, R., \& Mburugu, D. An Assessment of Public Primary School Teachers' Attitude towards Inclusion of Children with Hearing Impairment in Central Region of Kenya. International Journal of Education and Research, Vol. 2, No. (3), 2014: 1- 10.

[15] Leatherman, J., \& Niemeyer, J. Teachers' Attitudes toward Inclusion: Factors Influencing Classroom Practice, Journal of Early Childhood Teacher Education, Vol. 26, No. (1), 2005: 23-36.

[16] Monsen, J., \& Frederickson, N. Teachers' Attitudes towards Mainstreaming and Their Pupils' Perceptions of Their Classroom Learning Environment. Kluwer Academic Publishers, Vol. 7, 2004: 129-142.

[17] Monsen, J., Ewing, D., \& Kwoka, M. Teachers' Attitudes towards Inclusion, Perceived Adequacy of Support and Classroom Learning Environment. Learning Environments Research, Vol. 17, No. (1), 2014: 113-126.

[18] Parhoon, K., Movallali, G., Hassanzadeh, S., \& Moravej, M. Attitude of Regular and Itinerant Teachers Towards the Inclusion of Hearing Impairment Children. Iranian Rehabilitation Journal, Vol. 12, No. (22).2014: 22- 28.

[19] Todorovic, J., Stojiljkovic, S., Ristanic, S., \& Djigic, G. Attitudes towards Inclusive Education and Dimensions of Teacher's Personality. Procedia - Social and Behavioral Sciences, Vol. 29, 2011: $426-432$. 